\title{
RETHINKING LEGALITY OF STATE RESPONSIBILITY CLAIM ON CLIMATE CHANGE IN INTERNATIONAL LAW PERSPECTIVE
}

\author{
Mada Apriandi Zuhir \\ Law Faculty of Universitas Sriwijaya, Indonesia \\ E-mail: madazuhir@yahoo.com.sg \\ and \\ Ida Nurlinda, A. A. Dajaan Imami, and Idris \\ Law Faculty of Universitas Padjadjaran, Bandung, Indonesia
}

\begin{abstract}
Each state has sovereign right to explore and exploit their natural resources, however, it is also followed by state responsibility. This article examines the regime of state responsibility and the regime of climate change. State responsibility is applied to examine the implementation of international law toward climate change issues. This is a normative-juridical research by applying analytical descriptive approach. In the meantime, main data are secondary data (primary, secondary and tertiary legal materials). Then, the data were qualitatively analyzed. Based on the discussion it can be concluded that the regime of state responsibility in international law can be applied to the issue of climate change although this regime has limitations in its implementation. Therefore, it is advisable to have an independent and specific regime related to the state responsibility on climate change issues.
\end{abstract}

Keywords: international law, climate change, state responsibility

\begin{abstract}
Abstrak
Setiap negara memiliki hak berdaulat untuk mengeksplorasi dan mengeksploitasi sumber daya alam yang mereka miliki, namun hak tersebut diikuti juga dengan tanggung jawab negara. Artikel ini mengkaji rezim tanggung jawab negara dan rezim perubahan iklim. Tanggung jawab negara digunakan untuk menguji penerapan hukum internasional terhadap persoalan perubahan iklim. Pendekatan yang digunakan adalah yuridis normatif. Spesifikasi penelitian yang digunakan adalah deskriptif analitis. Sedangkan data utama yang digunakan adalah data sekunder (bahan-bahan hukum primer, sekunder dan tersier). Kemudian, data tersebut dianalisis secara kualitatif. Berdasarkan diskusi dan pembahasan disimpulkan bahwa rezim tanggung jawab negara dalam hukum internasional dapat diterapkan pada persoalan perubahan iklim, walaupun rezim ini memiliki keterbatasan dalam penerapannya. Oleh karenanya, disarankan perlu adanya sebuah rezim yang mandiri dan khusus terkait tanggung jawab negara dalam isu perubahan iklim.
\end{abstract}

Kata kunci: hukum internasional, perubahan iklim, tanggung jawab negara

\section{Introduction}

World climate change is one of global issues since it does not merely belong to one country and its impacts spread worldwide. In the last two decades, there is a discourse that nowadays has entered anthropocene, ${ }^{1}$ a concept

R Monastersky, "Anthropocene: The Human Age Momentum is Building to Establish A New Geological Epoch That Recognizes Humanity's Impact On The Planet. But There is Fierce Debate Behind the Scenes", Nature, Vol. 519, March 2015, London, UK: Macmillan Publisher Ltd, page 144-147; N F Sayre, "The Politics of the Anthropo- which declares that present geology process is dominated by human. ${ }^{2}$ This discourse tends to

genic"Annual Review of Anthropology, Vol. 41, October 2012, Palo Alto, CA USA: Annual Review, page 57-70.

2 R Potts, "Evolution and Environmental Change in Early Human Prehistory" Annual Review of Anthropology, Vol. 41 Oktober 2012, Palo Alto, CA USA: Annual Review, page 151-167; SA Crate, "Climate and Culture: Anthropology in the Era of Contemporary Climate Change" Annual Review of Anthropology, Vol. 40, October 2011, Palo Alto, CA USA: Annual Review, page 175-194; J D Proctor, "Saving nature in the Anthropocene," Journal of Environmental Studies and Sciences, Vol. 3 Issue 1, March 2013, US: Springer, page 83-92. 
strengthen the involvement of human in the earth development; thus, it is believed that the climate change is caused by human behavior in which it causes the change on biosphere since the revival of modern economy and industry through the use of carbon fuel that triggers the transformation in such a way that the parameters are relatively stable in Holocene. ${ }^{3}$

None has atmosphere; however, each country accumulatively contributes to the increasing of pollution through their emission. Even, if a country stops its pollution, it still gets the impacts resulted from the pollution of other countries. Therefore, the climate change is one of main environmental problems that is correlated to economic, social, and environmental interests of each country. Thus, international parties which are related to the issues of climate change declare climate change as "common concern of humankind". ${ }^{4}$

Each state has sovereign rights to the territory within its jurisdiction including exploring and exploiting its natural resources. It is inevitable in international law. However, those sovereign rights are limited by their obligations and the rights of other countries.

All this time, the discussions and the studies related to state responsibility are not only directed to general international law issues such as sovereignty violation and war but also to general environmental issues like marine pollution, nuclear activities, toxic and hazardous waste or pollution in general. ${ }^{5}$

Articles discussing the state responsibility in the framework of decision-making on climate change regime and from moral point of view deal with climate change as written by Toth and

3 P Crutzen dan S Eugene, "The Anthropocene", Global Change Newsletter, Vol. 41, 2000, page 17; F. Ferrando, "The Party of the Anthropocene; Post Humanism, Environmentalism and the Post Anthropocentric Paradigm Shift" Relations, Vol. 4 No. 2, November 2016, Milan, Italy: LED edizioni Universitarie, page 159-173.

Preamble of UNFCCC 1992.

5 J Brunnee, "Enforcement Mechanism in International Law and International Environmental Law. Environmental Law Network International Law Review 2005, Bingen Germany: ELNI, page 3-13; J B Skjaerseth, O Stokke and J Wettestad. "Soft Law, Hard Law and Effective Implementation of International Environmental Law". Global Environmental Politics Vol. 6 No. 3, August 2006. Cambridge: MITPress, page 104-120.
Fussel. ${ }^{6}$ Another article is written by RSJ Tol and $\mathrm{R}$ Verheyen discussing the state responsibility of the failure in regulating their emissions but not analyzing the possibility of responsibility claim both in national and international courts excluding analysis of the Resolution of UN Gen-eral Assembly No. 56/83 on January 28th, 2002 on the Responsibility of States for internationally wrongful acts (then it is called UNGA Res. 56/83). ${ }^{7}$

In practice, there is no case related to climate change that is brought to international court, although the claims filed through national justice process related to climate change have been considerable in number. ${ }^{8}$

If it is studied in the context of international environmental law, climate change issues have specific characteristics. These characteristics emerge since atmosphere is a kind of different territory and the environmental impacts are not derived from atmosphere change. Rather, it is caused by greenhouse emission which influences atmosphere capability to capture solar radiation; hence, it causes drought, flood, desertification, etc. ${ }^{9}$

Thus, as described above, in the context of climate change, the claim of state responsibility is worth discussing. State responsibility is used to examine the application of international law to climate change issues.

6 F L Toth. et. all, "Decision-Making Frameworks" in B. Metz, O Davidson, R J Swart, and J Pan, (Eds.), 2001, Climate Change 2001: Mitigation, Report of Working Group III of the Intergovernmental Panel on Climate Change. Cambridge University Press, Cambridge, page 603-673; H M Fussel, "How Inequitable is the Global Distribution of Responsibility, Capability, and Vulnerability to Climate Change: A Comprehensive Indicator-Based Assessment," Global Environmental Change Vol. 20 Issue 4, October 2010, Copenhagen: Elsevier Itd, page 597-611.

7 RSJ Tol and R Verheyen, "State Responsibility and Compensation For Climate Change Damages-A Legal and Economic Assessment" Energy Policy 32, 2004, Copenhagen: Elsevier Ltd, page 1110.

8 M B Gerrard, J. C. Howe, L. M. Barry, "the US and NonUS Climate Litigation Chart", Center for Climate Change Law, Columbia University. October $3^{\text {rd }}$, 2016, accessed on http://www.law.columbia.edu/centers/climate change.

9 Mada Apriandi Zuhir. "The Evaluation Of the Effectiveness of International Environmental Law With Reference to the Issue Of Global Climate Change", Simbur Cahaya. Vol. 47, XVII Edition, 2012, Palembang: Faculty of Law Universitas Sriwijaya, page 2903. 
Focusing on the specific characteristics as formulated by international instruments related to climate change which are different from environmental damage in general, legal question that arises in the context of internationally state responsibility is whether climate change regime and international law provide the possibility for affected countries to make claims and receive compensation for the impacts or not. If a country is possible to be asked for their responsibility for the impacts of climate change, to whom the burden of responsibility is imposed, how the distribution of the burden and what kind of loss that can be claimed. As it is known, based on the history of emission, in climate change regime, the burden is only addressed to the industrial countries due to their past activities, while at this moment, all countries contribute accumulatively to global emission, even emitter countries are also affected. Therefore, what are being questioned are how the related elements and the causal relation are and what kind of legal act which will raise state responsibility internationally is.

Obviously, to answer these questions requires a study of existing theories, concepts and doctrines as well as an analysis of international law and international environmental law with respect to the prevailing state responsibility regime, general law principles, international customs, international judicial decisions and other international practices.

\section{Discussion}

\section{State Responsibility in International Law}

It is undoubtedly that state is the main and the most important subject of international law (par excellence). Generally, the subject of law can be interpreted as a supporter or an owner of rights and obligations. Thus, in the context of international law, state as the subject of international law has legal capacity to be the supporter of rights and obligations under the international law.

One of the basic principles in international law declares that a state cannot harm nor violate the rights of other states. Violating those rights which are the legal interest of other parties will bring the consequences, for example, there will be claims from other states for state responsibility. A state which harms or violates the rights must be responsible for its actions and it is obligated to compensate the losses suffered by other parties. ${ }^{10}$

This responsibility arises because of the nature of international law, the concepts of state sovereignty and equality among countries. In international law literature, state responsibility is divided into two namely responsibility for delictual liability and responsibility for contractual liability.

The bases of state responsibility theoritically are risk and error. Risk theory determines that a country is absolutely responsible for any activity that causes harmful effects even though the activity is legal. ${ }^{11}$ Then, this theory creates a principle of absolute liability (strict liability) or objective responsibility. An example of the application of this theory can be seen in the provision of Article 2 on Liability Convention Year 1972 which states that launching state shall be absolutely liable to pay compensation for damages on the surface earth or in the aircraft that is in flight where the damages and the accidents are caused by its space object.

In fault theory, state responsibility arises when the act of the state can be proved committing fault. An act can be said as a wrongful act if it is committed intentionally for bad intention or with unjustifiable negligence. Then, this theory creates a principle of subjective responsibility or liability based on fault. ${ }^{12}$

According to Article 2 of UNGA Res. 56/ 83 , it is formulated that the act done by a state can be considered as wrongful act under international law if: It can be attributed to that state (attribution of conduct to a state); and It broke the international obligation of the state itself (breach of an international obligation).

Until the end of the $20^{\text {th }}$ century, it is still believed that the emergence of state responsibility by those two elements above are inade-

\footnotetext{
10 MMN Shaw, 2008, International Law, (6 ${ }^{\text {th }}$ ed), Cambridge: Cambridge University Press, page 778.

11 lbid.

12 Ibid., page 543.
} 
quate. Yet, there must be elements of damage or loss for other parties or countries. In its development, the elements of damage or loss are no longer considered as a necessity in any case which can lead to state responsibility, for instance, a violation of the provisions of international law related to human rights. This violation of human rights is clearly wrongful act according to international law, although it does not harm other parties or countries.

Article 24 of the European Convention on Human Rights mentions that each state can file the objection to other parties without requiring the state that files the objection as a victim of human rights violation perpetrated by suspected state. Likewise, Article 2 of UNGA Res. 56/83 excludes terms of damages related to acts which can be considered as wrongful act under international law.

Articles of UNGA Res. $56 / 83$ on state responsibility for international wrongful act provide general rules of international law that reflect customary law with environmental rules arising from other international agreements and rules. ${ }^{13}$

In the context of state responsibility and environmental impacts, besides the articles existing in UNGA Res. 56/83, there are some other non-binding instruments related to state obligations. For instance, the statement of Brundtland Commission or World Commission on Environment and Development (WCED):

“...the state which carried out or permitted the activities shall ensure that compensation is provided should substantial harm occur in an area under national jurisdiction of another state or in an area beyond the limits of national jurisdiction". ${ }^{14}$

This statement is in line with Principle 12 of UNEP Year 1978 which determines that states are responsible for the fulfillment of their international obligations in the field of environment concerning the conservation and the utilization of shared natural resources. Those states are

\footnotetext{
13 P Sands, 2003, Principles of International Environmental Law, $\left(2^{\text {nd }} e d\right)$, Cambridge: Cambridge University Press, page 874

14 lbid.
}

the subject of the obligations related to the application of international law for environmental damage resulting from violation of these obligetions outside the border of their jurisdiction.

The confession to the practices of international liability has existed for long time and it can be seen in the decision of Permanent Court of International Justice (PCIJ) and International Court of Justice (ICJ), for instance, the statement which stated that international liability emerges soon after a state infringes other countries' rights. ${ }^{15} \mathrm{PCIJ}$ in the case of Spanish Zone of Morocco claims stated:

“...responsibility is the necessary corollary of a right. All rights of an international character involve international responsibility. Responsibility results in the duty to make reparation if the obligation in question is not met". ${ }^{16}$

Likewise in Chorzow factory case (1928), PCIJ stated:

"it is a principle of international law and even a greater conception of law that any breach of an engagement involves an obligation to make reparation". ${ }^{17}$

The main state responsibility for wrongful act under international law is the obligation to stop the wrongful act, ensure and guarantee appropriately that there will not be act repetition. If there is possibility to happen again, the full compensation for the loss caused by the wrongful act is obliged. ${ }^{18}$

The obligation of indemnity is sometimes called as liability. According to Sands, the term 'liability' in international law literature has been widely discussed, for example, PM Dupuy and $\mathrm{H}$ Smets give the meaning of liability as an international obligation to give compensation,

\footnotetext{
15 Phosphates in Morocco. Judgment. 1938. PCIJ, Series A/B No. 74, page 28 .

16 Ibid.

17 Chorzow Factory case, PCIJ, Series A No. 17, 1928, page 29.

18 J Crawford, 2002, The ILC's Articles on State Responsibility: Introduction, Text and Commentaries see also Report of the ILC, UN Doc. A/56/10(2001), J. Crawford, $1^{\text {st }}$ Report on State Responsibility, UN Doc. A/CN.4/490 and Add.1-7 (1998); $2^{\text {nd }}$ Report, UN Doc.A/ CN.4/498 and Add.1-4 (1999); $3^{\text {rd }}$ Report, UN Doc.A/CN. 4/507 and Add.1-4 (2000); $4^{\text {th }}$ Report, UN Doc.A/CN.4/ 517 (2001) See also P Sands. Loc. Cit.
} 
meanwhile Goldie gives the broader meaning that is the consequence of failure to do the job, or fulfillment of required performance standards. Consequently, liability has the connotetion of indemnity in law when responsibility and loss arise from the failure in the fulfillment of obligation. ${ }^{19}$

This rule in many cases is applied by ICJ, for instance, in Corfu Channel Case and Danube Dam Case (Gabcikvo-Nagymaros Project). ${ }^{20}$ These two cases will be frequently quoted in analysis of state responsibility internationally related to climate change in the next discussion.

Articles of United Nations General Assembly Resolution Number $56 / 83$ on January $28^{\text {th }}$, 2002 on Responsibility of States for Internationally Wrongful Acts

International Law Commission (ILC) is formed as a subsidiary organ for United Nations General Assembly, with purpose to promote and develop international law and its codification. ${ }^{21}$ In 1953, United Nations General Assembly asked ILC for codifying the law related to state responsibility. ${ }^{22}$ Then, Articles Draft of ILC is adopted and created as Annex in United Nations General Assembly Resolution Number 56/83 on January $28^{\text {th }}, 2002$.

UNGA Res $56 / 83$ is not officially binding every country, but it can form the basis of international agreement as part of countries' practices that can cause international customary law. As stated by Shaw, the Articles of ILC Year 2001 originally came from sources accepted by international law, especially concerning international customs as the evidence of the existence of general practices accepted as law by the states, principles of general law, and also judicial decision and the doctrine of the jurists as stated in Article 38 of Statuta ICJ. ${ }^{23}$

19 P Sands, Loc.Cit.

20 M Dixon and R McCorquodale, 2003, Cases and Materials on International Law. OxfordUniversity Press, page 411, 435

21 Statute of the International Law Commission, Article. 1.1 .

22 UNGA Res. 799 (VIII), December $7^{\text {th }}, 1953$ and see also UNGA Res. 32/151, December 19 1977.

23 M N Shaw. Op.Cit, page 113.
The basic rule of state responsibility as defined in Article 1 of UNGA Res. 56/83 is that: "every internationally wrongful act of a State entails the international responsibility of that State". The responsibility of state arises from an internationally wrongful act either an action or an omission as formulated in Article 2; therefore, the requirements to fulfil the nature of wrongful act in international law need to be discussed.

The requirements which can be submitted are divided into two elements namely subjecttive element and objective element. The subjective element aims at attribution between the wrongful act and the state while objective element is the failure of a state to fulfill its international obligations. ${ }^{24}$

The application of the attribution and the violation of obligation is clearly seen in PCIJ's decision in Phospates in Morocco case, in which $\mathrm{PCIJ}$ links the determination of international responsibility with an act being attributable to the State and described as contrary to the treaty right of another State. ${ }^{25}$

The important elements of wrongful act are further regulated in Article 2 of UNGA Res. 556/83 in sub-article: a). To subjective element, action or omission can be attributed to a state; and sub-article b). To objective element, act or omission is a violation toward an international obligation.

Subjective element of an internationally wrongful act is the attribution between the act which can be accounted for, with a state as an original and major subject of international law. 26

Since state is abstract, then attribution of the act of a state depends on the relation between the state and individual or group of people who commit the unlawful act. The relation between individual, group of people or a corporation and state is based on the principles

\footnotetext{
Ibid.

25 Phosphates in Morocco, Judgment, 1938, PCIJ, Series A/B No. 74, page 28

26 M N Shaw, Op.Cit, page 701.
} 
of nationality, residency, or both which are theoretically sufficient to link them. ${ }^{27}$

However, this kind of approach is avoided by international law because it will expand the responsibility of state far away from the involvement of the state itself as an organization. Besides, the international law admits the act that is done by individual or group of people autonomously or out of the state. ${ }^{28}$

Thus, the approach conducted to link an action and state as international law subject is based on the criteria decided by the international law. ${ }^{29}$

These criteria exist on Chapter II of UNGA Res. 56/58 which consist of eight articles. They are article 4 up to article 11 , which are cumulative and limited. They bring he different base of attribution. The cumulative effect of the criteria brings the consequence that a country is not responsible for the action which does not include the eight criteria.

In particular, according to Article 4 which stipulates the general rule of attribution, the act of state's organs must be considered as the act of the state itself. The act of state's organs such as state, government, and/or the officers (people or other entities which do the act under the command, advice, or supervision of those organs) that can be attributed to the state.

Those organs include the national, regional, or local governmental organs, and people or other entities whose status as governmental organ based on national law of a state. Besides, they also include people who act as governmental organ even though they are not classified as the part of the organ in national law.

Then, how is the wrongful act conducted by non-govermental people which results in international responsibility? International responsibility of a state arises due to the act conducted by those who are generally not the part of the govermental organ if the state is failed to prevent or to punish the act of those people.

27 Ibid.

28 Report of the ILC, UN doc.A/56/10.2001, page 38.

29 Ibid.
ILC considers it as the cumulative effect of Chapter II of UNGA Res. 56/83, which declares that a state is responsible for the impact of non-govermental people's act since the state has failed to make appropriate response to the things that already happened. For instance, the decision of ICJ related to the case of United State Diplomatic and Consular Staff in Tehran. According to ICJ, Islamic Republic of Iran is responsible for their failure to take the right steps in order to protect the US Embassy and the diplomatic and consular staffs from millitant revolutionary action, not for the occupation and the hostage of embassy itself. ${ }^{30}$

The objective element of internationally wrongful act stated that the act, in which the state responsibility arises, must be the breach of international obligation. ${ }^{31}$ According to Article 2 of UNGA Res. $56 / 83$, the act or the omission is a breach of international obligation of the state. In ILC report Year 2001, the breach of an obligation is similar to the act opposing the rights of others. ${ }^{32}$ The use of another term for this case is on the Decision of PCIJ on Phosphates in Morocco case which refers to the act which is contrary to the right of another state. ${ }^{33}$ According to Rainbow Warrior Arbitration, it refers to every breach by a state of any obligation. ${ }^{34}$ Other terms used are breach of an engagement, violation of an international obligation and acts incompatible with international obligations. ${ }^{35}$

According to Article 2 of UNGA Res 56/83, the breach of international obligation can be in the forms of act and omission. The basic reason is that it is not only positive action but also an omission which can cause wrongful acts. ${ }^{36}$

30 M Dixon and R McCorquodale, 2003, Op.Cit., page 413; United States Diplomatic and Consular Staff in Tehran case (USA vs Iran), Judgment, I.C.J. Reports 1980. page 3.

31 Report of the ILC, UN doc.A/56/10, 2001, page 34.

32 Ibid., page 35.

33 Phosphates in Morocco, Judgment, 1938, PCIJ, Series A/B No. 74, page 28.

34 Rainbow Warrior Arbitration (New Zealand vs France) (1990), See M Dixon and R McCorquodale, 2003, Op.Cit., page 434.

35 Report of the ILC, UN doc. A/56/10, 2001, page 35.

36 Ibid. 
Moreover, the report of ILC Year 2001 stated that it is difficult to separate the omission from other relevant cases which arise responsibility. In practice, the number of state responsibility which appears due to certain act is as same as the number of state responsibility which arises due to omission. ${ }^{37}$ The case describing wrongful act which comes from omission is the case of United States Diplomatic and Consular Staff in Tehran. Another example is the case of Corfu Channel in which Albania is responsible for the damage caused by two destroyer ships from United Kingdom when they crashed a mine in Albania's sea although the mine was not located there by Albania. ${ }^{38}$ ICJ concluded that Albania must know about the location of the mine and they should warn UK before.

Related to the broken obligation, it must have international character (Article 3 of UNGA Res. 56/83). Hence, the breach of obligation caused by national obligation is not enough to enter this criteria. In addition, a state cannot take off the action characteristics of the breach by declaring that the action is conducted based on the national law of the state. Otherwise, the state responsibility is a consequence of international law breach and it cannot be abandoned based on the national law and regulation of the state itself.

This state responsibility regime is generally applied, either for the breach of agreement or the breach of other law obligations, and it does not distinct the origin of the broken norm, whether it is civil or criminal obligation like in national law system. ${ }^{39}$

Related to the parties, the obligation must be valid among the countries involved in the actions as it is formulated in Article 12 of ILC Year 2001, ("there is a breach of an international obligation by a State when an act of that state is not in conformity with what is required of it by that obligation, regardless of its

37 Ibid.

38 Corfu Channel Case (United Kingdom vs Albania), Judgment of April $9^{\text {th }}, 1949$, I. C. J. Reports 1949, page 4.

39 Report of the ILC, UN doc. A/56/10, 2001, page 35. origin or character"). Otherwise, a state is not responsible for the breach of obligation of an agreement if the state does not ratify the intended agreement.

These provisions are also consistent with non-retrospective principle and confirmed to be applied regarding with the problem of state responsibility. ${ }^{40}$ However, this matter cannot be considered as an obstacle to the interpretation of agreement condition which is completely different; hence, it should be allowed for certain cases. ${ }^{41}$

As an example, the assesment of ICJ for Danube Dam (Gabcikovo-Nagymaros Project case) case which pointed out new scientific opinion and new legal norm needs to be considered. ${ }^{42}$ In this case, the issues began to appear. It is not only about violation and breaking of agreement and state succession but also about environmental issues. This case is given to ICJ based on spesific agreement between Hungary and Slovakia (as the successor of Czech and Slovakia) in 1995 considering that the case can be given to ICJ as long as both parties agree. Nonetheless, ICJ then emphasized that new and emerging norms in environmental law are relevant in the implementation of the agreement ${ }^{43}$ and recognize the vulnerability of environmental capability based on environmental risks that have been assessed, ${ }^{44}$ the ICJ has decided that the agreement is still in effect and Hungary has no right to terminate the agreement as pronounced by ICJ that:

"termination on the basis of a breach which has not yet occurred, such as Hungary's purported termination of a bilateral treaty on the basis of works done by Czechoslovakia which had not at the time resulted in a diversion of the Danube River, would be deemed premature and would not be lawful". ${ }^{45}$

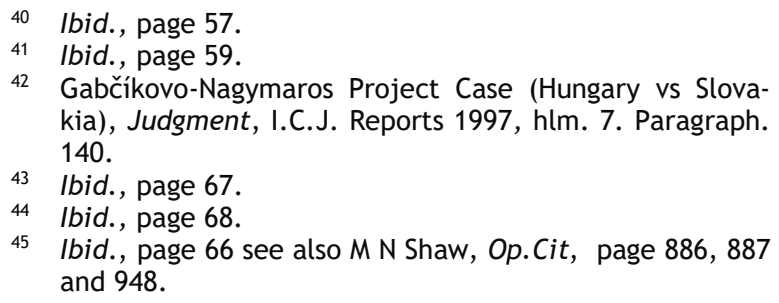

Gabčíkovo-Nagymaros Project Case (Hungary vs Slovakia), Judgment, I.C.J. Reports 1997, hlm. 7. Paragraph. 140.

$43 \quad$ Ibid., page 67.

44 Ibid., page 68.

45 Ibid., page 66 see also M N Shaw, Op.Cit, page 886, 887 and 948. 
This is also in accordance with the provision of Article 31 paragraph 3 (c) of the Vienna Convention Year 1969 on the Law of International Agreement, which states that any relevant international legal provision among the parties shall be taken into consideration when interpreting the terms of the agreement.

The articles of ILC Year 2001 according to Sans generally can be applied to internal environmental law (including climate change issues), to the extent that they reflect international customary law. ${ }^{46}$ However, the general rule contained in ILC Year 2001 cannot be applied if the general rules violate a special and independent regime. The rules contained in a special or independent regime that are applied based on the principle of lex specialis lex generalis. The relationship between specific legal norms and general legal norms is reflected in Article 55 of UNGA Res. 56/83 which formulates:

These articles do not apply where and to the extent that the provisions for the existence of an internationally wrongful act or the content or implementation of the international responsibility of a State are governed by special rules of international law.

\section{Legal Consequences of Internationally State Responsibility}

As explained earlier, since every internationally wrongful act done by a state attaches international responsibility to the state, the act then creates new international legal obligation. ${ }^{47}$ The new international legal obligation, according to UNGA Res. $56 / 83$ is to abolish the consequences arising from wrongful act through cessation. ${ }^{48}$ This is the first thing to do. Cessation, referring to Article 30 of UNGA Res. 56/83, is the state responsibility to stop the act, if it is still in the process, and it provides no guarantee of repetition. The purpose of this cessation is to stop any violation that incurs such international obligations and to protect the sustainability of

46 P Sands, 2003, Op.Cit., page 873.

47 See also Report of the ILC, UN doc. A/56/10, 2001, page 86.

48 Ibid., page 89. the validity and effectiveness of the breached obligations. ${ }^{49}$

Furthermore, the state is required to provide reparation fully on the consequences, as PCIJ's Decision in the case of Factory at Chorzow which states:

"is that reparation must, as far as possible, wipe-out all the consequences of the illegal act and re-establish the situation which would, in all probability, have existed if that act had not been committed. Restitution in kind, or, if this is not possible, payment of a sum corresponding to the value which a restitution in kind would bear; the award, if need be, of damages for loss sustained which would not be covered by restitution in kind or payment in place of it - such are the principles which should serve to determine the amount of compensation due for an act contrary to international law". ${ }^{50}$

In Article 34 of UNGA Res. 56/83, the forms of full reparation are restitution, compensation and satisfaction, either individually or in combination ("Full reparation for the injury caused by the internationally wrongful act shall take the form of restitution, compensation and satisfaction, either singly or in combination, in accordance with the provisions of this chapter").

In the principle of law, restitution is the main thing compared to compensation, but in many cases there is a possibility of being unavailable or insufficient. If it happens, then the compensation is given to offset the gap that is not fulfilled by the reparation. ${ }^{51}$

Compensation as a form of reparation does not involve the punishment of state responsibility; it only concerns the actual harm resulting from the internationally wrongful act. This compensation usually consists of monetary payments, intended as a counterweight to losses suffered by a country for the offense. The existence of a causal relationship between actions and losses is a necessary prerequisite in compensation, in addition to terms of direct-

\footnotetext{
49 Ibid.,

50 Factory at Chorzów case, Merits, Judgment, 1928, PCIJ, Ser.A, No. 17, page 47.

51 Report of the ILC, UN doc. A/56/10, 2001, page 99.
} 
ness, foreseeability or proximity, as well as other factors that may be related to whether the actions of the state organs that cause harm are indeed in purpose or not.

As arranged in Article 31 paragraph 2 of UNGA Res. 56/83, the intended losses include both material and moral damages. However, the liability for compensation is limited to financial assessable damages in terms of property and state personnel, reasonable expenditures to deal with or mitigate damages arising from such acts, and the damage suffered by the citizens, persons and company. Nonmaterial damage can only be theoretically evaluated in financial terms and in the form of compensation in the form of satisfaction.

In cases related to threat in form of environmental damage, the suffering state will be given a compensation to pay state spending upon a proper cost which appear in preventing or handling pollution. It also can be as payment on value reduction of affected property. ${ }^{52}$

In Trail Smelter case, United State had been given a compensation upon damaged land and property caused by emission from Smelter Canada. ${ }^{53}$ However, as stated in the comment of ILC Year 2001, in many cases, this environmental damage included as a damage which cannot be compensated just by cleaning cost or any compensation for property devaluation. However, sometimes it can be non-use values, for instance the loss of biodiversity, which is difficult to be measured with money. ${ }^{54}$

\section{Implementation of State Responsibility on Cli- mate Change Impacts}

International agreement related to climate change consists of UNFCCC 1922 and Kyoto Protocol 1997 also the results of conference of all the parties, including Paris Agreement 2015. UNFCCC 1992 mainly focuses on climate change mitigation and it does not regulate how damage caused by climate change must be compensated. Kyoto Protocol gives mechanism upon disobedience, but it only concerns the sanction

\footnotetext{
52 Ibid., page 101.

53 Ibid., page 101.

54 Ibid., page 101.
}

of failure to fulfill particular obligation like target of emission. There is no law consequences upon damage caused by climate change. Another agreement for instance Paris Agreement 2015 through Decision 1/CP.21 agrees that Article 8 of the Agreement does not involve or provide a basis for any liability or compensation. This consideration excludes the basis and the claim of state responsibility on the impacts of climate change.

Therefore, the main international agreements of this global climate change do not have specific and independent responsibility regime; thus, lex specialis derogat lex generalis principle cannot be applied like the formulation of Article 55 of UNGA Res.56/83.

Not only climate change regime, related to environment in general as it was introduced by Sands, there are no international instruments which codify international law especially about state responsibility and state obligation. ${ }^{55}$ The absence of specific and independent regime concerning state responsibility in environmental and climate change sector, could be the foundation of the application of UNGA Res. 56/83 on state responsibility in international agreement and other international rules in international environmental law sector as a reflection of international customary law development. This statement is an argument of UNGA Res. 56/83 application toward the global climate change issues by developing Sands' opinion (2003), that:

"The ILC's Articles on State Responsibility bring together the rules of general international law, and they are applicable (to the extent they reflect customary law) with environmental rules established by treaties and other internationally applicable rules". .56

The application of state responsibilitty in environmental damage case actually has been confirmed by ICJ in Danube Dam Case (GabcikovoNagymaros Project), even though Birnie and Boyle stated that nowadays big pollution disasters are Chernobyl, Sandoz, and Amoco Cadiz. There is no international claim regarding state

55 P Sands, Op.Cit, page 873.

Ibid 
responsibility due to disasters. ${ }^{57}$ Furthermore, Sands said that generally law of state responsibility has developed, but on the other hand, it does not develop when it is attributed to environmental damage. ${ }^{58}$

There is particular characteristics of environmental damage, for instance, complexity of causality mechanism related to causal relation which is cumulative; therefore, the environmental damage as climate change impact does not fullfil the criteria of current state responsibility regime.

In the explanation about loss, ILC said that the relation between loss and its wrongful act must have proximate cause. Loss that is indirectly related, too remote or uncertain to be apparised. It is not a sufficient condition to result indeminity. ${ }^{59}$

Hence, now in relation with the implementation of state responsibility because of climate change, what must be clarified is the identification of international obligation element that is broken and attribution element of wrongful act in a state. Related to the doer state, in the case of global climate change, there are many states which are involved as doer states, so is it possible to file claim of state responsibility to one or several states meanwhile in fact all states contribute cumulatively in giving GRK emission.

International law including Article 1 of UNGA Res. 56/83 clearly stated that every internationally wrongful act done by a state causes international responsibility to the state itself. It is surely not an exception if the wrongful act is done by many states or the loss is suffered not only by one state but also many states, so the rule must be neglected.

Basic international law regulation stated that each state is responsible for its own conduct in respect of its own obligations. ${ }^{60}$ However, basic knowledge existing in Article 1 of UNGA Res. 56/83 cocerning state responsibility covers new relationship arising according to international law of wrongful act of a state, with-

\footnotetext{
57 P Birnie and A Boyle, 2002, International Law and The Environment $\left(2^{\text {nd }} e d\right)$ London; Oxford Press, page 178.

$58 \quad$ P Sands. Op.cit, page 869.

59 Report of the ILC, UN doc. A/56/10, 2001, page 92-93.

60 Ibid., page 34.
}

out considering international law subject involved.

Therefore, the amount of states that conducts wrongful act and the amount of states that suffers the damage do not hamper the claim of responsibility of one or more states in this context. The report of ILC Year 2001 stated:

"Thus the term "international responsibility" in Article 1 covers the relations which arise under international law from the internationally wrongful act of a State, whether such relations are limited to the wrongdoing State and one injured State or whether they extend also to other States or indeed to other subjects of international law, and whether they are centred on obligations of restitution or compensation or also give the injured State the possibility of responding by way of countermeasures". ${ }^{61}$

Regarding how these costs are allocated, Voigt offers a cost allocation based on what percentage of a state's contribution to the total global emissions, or it can be based on an agreement by considering the principle of common but differentiated. ${ }^{62}$

Furthermore, what if the state from which wrongful act raises international responsibility is the one state that suffers losses for such action? Based on Article 39 of UNGA Res. $56 / 83$ related to the number of subjects involved, many emitter states which cause emissions and also at the same time a victim or a state experiencing losses due to GRK (Green House Gas), then, if the country that suffers such losses intentionally, by negligence, or its negligence contributes to the loss on their own, it will affect in a degree of reparation from the rights owned by the state, and that does not mean relieving them of international responsibility. Article 39 of UNGA Res. 56/83 formulates:

\footnotetext{
Ibid, page 33.

62 C Voigt, "State Responsibility for Climate Change Damages", Nordic Journal of International Law, Vol. 77 No. 1/2, 2008, Leiden: Brill Nijhoff Publisher, page 19; T Deleuil. "the Common But Differentiated Responsibilities Principle: Changes in Continuity After the Durban Conference of the Parties", Reciel, Vol. 21 No. 3, 2012, UK: Blackwell Publishing Ltd, page 271-281.
} 
"In the determination of reparation, the account shall be taken off by the State or any other person or entity in relation to whom reparation is sought".

In relation to anthropogenic climate change issues involving complex causal mechanisms, it must be separated whether anthropogenic climate change is caused by human activity or caused by nature. It is already explained in the previous section that carbon dioxide and greenhouse emissions are not the cause of environmental damage. Carbon dioxide and Greenhouse emissions only trigger the chain of events, which then lead to climate change associated with the damage that occurs. By this understanding, it is difficult to make Greenhouse gas as the cause of the occuring damage. Therefore, it is necessary to build argumentation of correlation between the emission by a state and the damage experienced by other states.

Till present, the basis of international instruments related to climate change issues and beliefs of the adverse effects of climate change refers only to the scientific evidence in scientific reports accumulated by IPCC scientists. In this case, the issue of climate change is difficult to be categorized into the regime of state responsibility because it becomes an unrealistic thing to identify the injury on the basis of certain emissions. Therefore, then in relation to direct causal relationship, it should be developed that the defects can be proved the causality and built on the possibility of scientific evidence contained in the argument of scientific data as direct evidence.

The basis of this statement can be used with reference to the Trail Smelter case, where the court considers that sufficient evidence of the damage was caused by the data of sulfur di-oxide emissions from the smelter. ${ }^{63}$

The case of the Trail Smelter, according to Martin Dixon and Robert McCorquodale is a preventative principle and Principle 21 of the Stockholm Declaration and Principle 2 of the Rio Declaration which is repeated in international

63 M Dixon and R McCorquodale, 2003, Op.Cit., page. 467; Trail Smelter Arbitration (United States vs Canada) April $16^{\text {th }}, 1938$, March $11^{\text {th }}, 1941 ; 3$ RIAA 1907 (1941). instruments that is an international customary law including international judicial decisions such as the 1995 Nuclear Test Case between New Zealand vs France. ${ }^{64}$

Furthermore, UNGA Res. 56/83 provides an understanding of injury as both material and moral damages. In this understanding, the damage caused by the effects of climate change is included. Yet, as it is known that the impacts are not only on property and health, but also on other biological and ecological diversity.

Consequently, it is difficult to estimate non-material losses to convert it into the value of money, if it is only based on factual and objective standards. Still, as Voigt argues, the evaluation of public property is more difficult than private one where the evaluation of privately owned resources can be estimated based on market value. ${ }^{65}$ Regard to the destruction of public property, full compensation for the damage as a result of climate change is impossible, since ecological intrinsic values cannot be valued with money.

\section{Conclusion}

The regime of state responsibility in international law as reflected in UNGA Res. $56 / 83$ can be applied to the issue of climate change because this global climate change regime has no independent and specific responsibility regime. Although the articles of UNGA Res. 56/83 can be used as a basis for claims of state responsibility for climate change, the regime has limitations in its application.

Substantively, the issues of climate change have particular characteristics, such as the complexity of causal mechanism and evidence related to numerous and cumulative causation, so the environmental damage as an impact of climate change does not qualify the criteria of the current state responsibility regime.

Therefore, it is necessary to establish an argument for linkage of emissions by a state to the damage experienced by other states based on emissions data in scientific reports as direct evidence of possible environmental damage by referring to the existing international cases.

\footnotetext{
M. Dixon and R McCorquodale, 2003, Ibid.

65 C Voigt, 2008, Op. Cit, page 18.
} 


\section{Suggestion}

At international level, it is necessary to develop a special and independent regime of state responsibility related to climate change. In view of the current regime of state responsibility in international law, particularly the UNGA Res. 56/83 does not adequately accommodate climate change issues that have their own characteristics.

\section{References}

Birnie, P and ABoyle, 2002. International Law and The Environment $\left(2^{\text {nd }} e d\right)$ London; Oxford Press;

Brunnee, J. "Enforcement Mechanism in International Law and International Environmental Law", Environmental Law Network International Law Review 2005, Bingen Germany; ELNI;

Crate, S. A. "Climate and Culture: Anthropology in the Era of Contemporary Climate Change" Annual Review of Anthropology. Vol. 40. October 2011. Palo Alto, CA USA: Annual Review;

Crutzen, P. and S Eugene. "The Anthropocene". Global Change Newsletter. 41. 2000;

Deleuil, T. "the Common But Differentiated Responsibilities Principle: Changes in Continuity After the Durban Conference of the Parties". Reciel. Vol. 21 No. 3. 2012. UK: Blackwell Publishing Ltd;

Dixon, M. dan R McCorquodale. 2003. Cases and Materials on International Law. Oxford University Press;

Fernando, F. "The Party of the Anthropocene; Post Humanism, Environmentalism and the Post Anthropocentric Paradigm Shift". Relations. Vol. 4 No. 2. November 2016. Milan: LED edizioni Universitarie;

Fussel, HM. "How Inequitable is the Global Distribution of Responsibility, Capability, and Vulnerability to Climate Change: A Comprehensive Indicator-Based Assessment". Global Environmental Change. Vol. 20 Issue 4. October 2010. Copenhagen: Elsevier Ltd;

Gerrard, MB. JC Howe. LM Barry. October $3^{\text {rd }}$, 2016 "the US and Non-US Climate Litigation Chart", Center for Climate Change Law, Columbia University. Available on web: http://www.law.columbia.edu/cen ters/climatechange. Accessed on November $5^{\text {th }}, 2016$;

Metz, B. O Davidson. RJ Swart, and RJ Pan. 2001. Climate Change 2001: Mitigation, Report of Working Group III of the Intergovern-mental Panel on Climate Change. Cambridge: Cambridge University Press.

Monastersky, R. "Anthropocene: The Human Age Momentum is Building to Establish A New Geological Epoch That Recognizes Humanity's Impact On The Planet. But There is Fierce Debate Behind the Scenes". Nature. Vol. 519. March 2015, London: Macmillan Publisher Ltd.

Potts, "Evolution and Environmental Change in Early Human Prehistory".Annual Review of Anthropology. Vol. 41. October 2012. Palo Alto, CA USA: Annual Review;

Proctor, JD. "Saving nature in the Anthropocene". Journal of Environmental Studies and Sciences. Vol. 3 Issue 1. March 2013. US: Springer;

Sands, P. 2003. Principles of International Environmental Law. ( $\left.{ }^{\text {nd }} \mathrm{ed}\right)$. Cambridge: Cambridge University Press.

Sayre, NF. "The Politics of the Anthropogenic". Annual Review of Anthropology. Vol. 41. October 2012. Palo Alto, CA USA: Annual Review.

Shaw, M. N. 2008. International Law. (6 ${ }^{\text {th }}$ ed). Cambridge: Cambridge University Press.

Skjaerseth, JB. O Stokke and J Wettestad."Soft Law, Hard Law and Effective Implementation of International Environmental Law". Global Environmental Politics. Vol. 6 No. 3. August 2006. Cambridge: MITPress;

Tol, RSJ and R Verheyen."State Responsibility and Compensation For Climate Change Damages - A Legal and Economic Assessment”. Energy Policy. 32. 2004. Copenhagen: Elsevier Ltd;

Voigt, C. "State Responsibility for Climate Change Damages". Nordic Journal of International Law. Vol. 77 No. 1/2. 2008, Leiden: Brill Nijhoff Publisher;

Zuhir, Mada Apriandi. "The Evaluation Of the Effectiveness of International Environmental Law With Reference to the Issue Of Global Climate Change". Simbur Cahaya. Vol. 47 XVII Edition. 2012. Palembang: Faculty of Law Universitas Sriwijaya. 